\title{
SECURING
}

LAND ACCESS

FOR WOMEN

An innovative process based on social legitimacy 


\section{July 2020}

English edition (translated from French)

This guide was produced by:

\section{Harouna Bary}

Groupe de Recherche et d'Action sur le Foncier

Fatoumata Tall

Groupe de Recherche et d'Action sur le Foncier

\section{Saydou Koudougou}

Groupe de Recherche et d'Action sur le Foncier

Larissa Stiem-Bhatia

TMG Research gGmbH

\section{Dr. Saïdou Sanou}

Groupe de Recherche et d'Action sur le Foncier

It also incorporates the contributions of the participants of the workshop organised to share and enrich this technical guide, held on 28 June 2018 in Ouagadougou, Burkina Faso.

\section{Acknowledgement}

We would like to thank all the participants in the process of securing land rights for women in Tiarako, particularly the population of Tiarako as a whole, the mayor of Satiri, the Prefecture and the decentralised technical services of Satiri, as well as our partner, the Deutsche Gesellschaft für Internationale Zusammenarbeit (GIZ) GmbH.

\section{Contact}

koudougousaydou@yahoo.fr

larissa.stiem-bhatia@tmg-thinktank.com

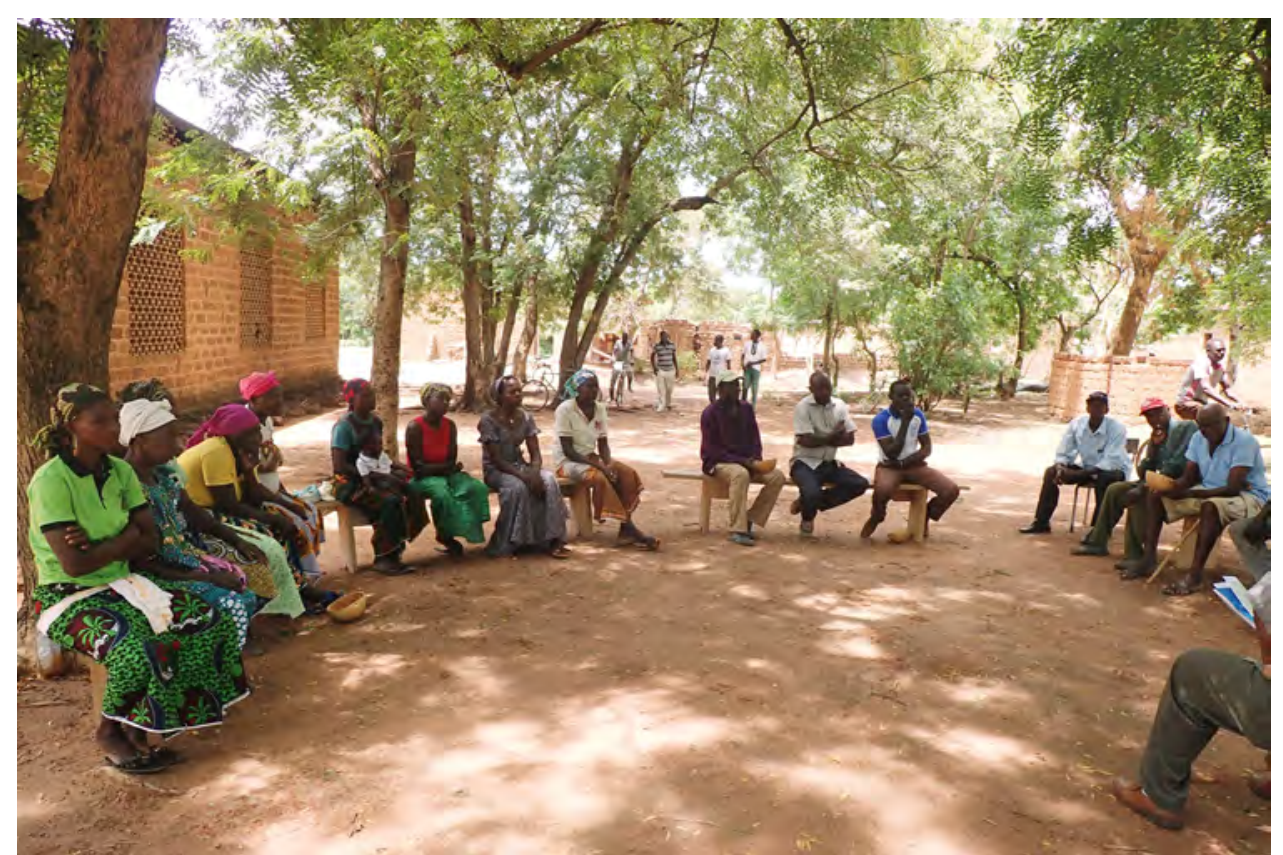

Reflection meeting after the securing of land rights process. (c) L. Stiem-Bhatia/TMG Research 


\section{Table of contents}

List of acronyms and abbreviations

About the guide

Land tenure insecurity - a central challenge to agricultural productivity

Agriculture, and land degradation

Land tenure insecurity: an obstacle to the adoption of SLM techniques

\section{Access to land for women in Burkina Faso}

Limited implementation of land reforms

How to successfully secure

land access for women

Securing land access in a context of weak legal

implementation

Key steps in the process

Guiding principles for a successful process

Conclusion

References

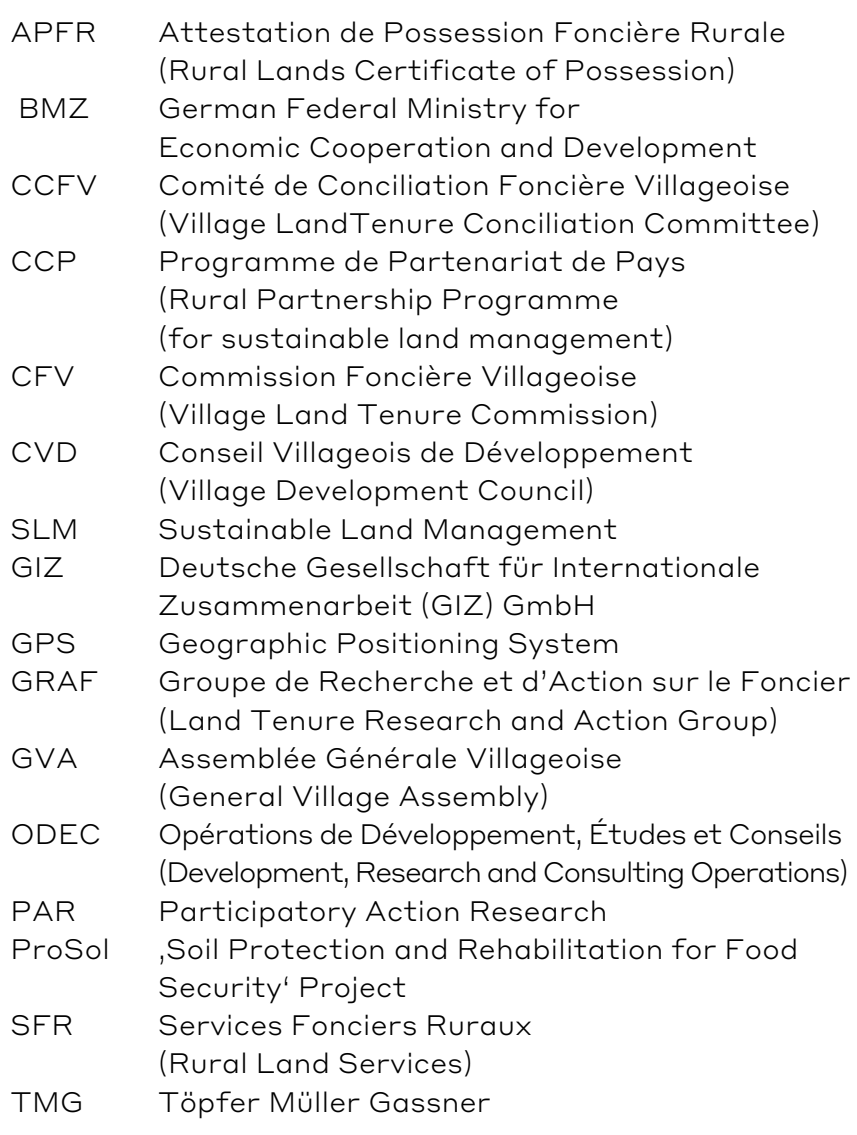

Opérations de Développement, Etudes et Conseils
(Development, Research and Consulting Operations)

Participatory Action Research

ProSol Soil Protection and Rehabilitation for Food Security' Project

SFR Services Fonciers Ruraux

(Rural Land Services) 


\section{About the guide}

This second edition contains lessons learned from continuous monitoring and evaluation of the land right transfer process piloted in the village of Tiarako.

The purpose of this guide is to provide development practitioners with guidelines for the conduct of an alternative process to secure land access for women. Land access needs to be secured particularly where legal and regulatory provisions have been adopted and implemented to a limited extent only, and where customary land regimes are still prevalent.

The guide is the outcome of Participatory Action Research (PAR) carried out by Groupe de Recherche et d'Action sur le Foncier (GRAF) and TMG Research g GmbH (TMG).

This action research was carried out within a research project accompanying the Soil Protection and Rehabilitation for Food Security project, implemented by the German Development Agency GIZ in the Hauts-Bassins region of Burkina Faso. Both projects are part of the 'One World, No Hunger' initiative financed by the German Federal Ministry for Economic Cooperation and Development (BMZ).

The research was developed in cooperation with the people of Tiarako, the Satiri municipal council, decentralised technical services, and GIZ. The initiative, founded on the principle of social legitimacy, secured access to land for 228 women. This guide summarises this process and outlines the different steps required to achieve the stabilisation of land rights for women. It incorporates lessons learned from the process and the outcomes of the workshops that followed it.

This guide is aimed mainly at the following actors: farmers' organisations; technical services responsible for rural sector management (agriculture, animal resources, environment) and for the promotion of women; technical and financial development cooperation partners; and stakeholders involved in projects and programmes on land governance, natural resource management, agriculture and rural development.

\section{The project is also the subject of a documentary.}

Watch the documentary 'Tiarako s'engage pour l'accès sécurisé à la terres (in French)

here:

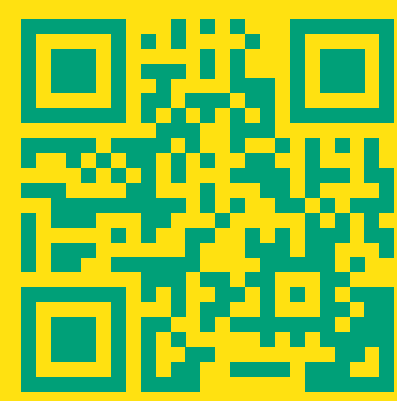

https://www.youtube.com/watch?v=2×5PECCTI4U

\author{
For further information, please visit our \\ websites: \\ www.soilmates.org \\ www.graf-bf.org
}




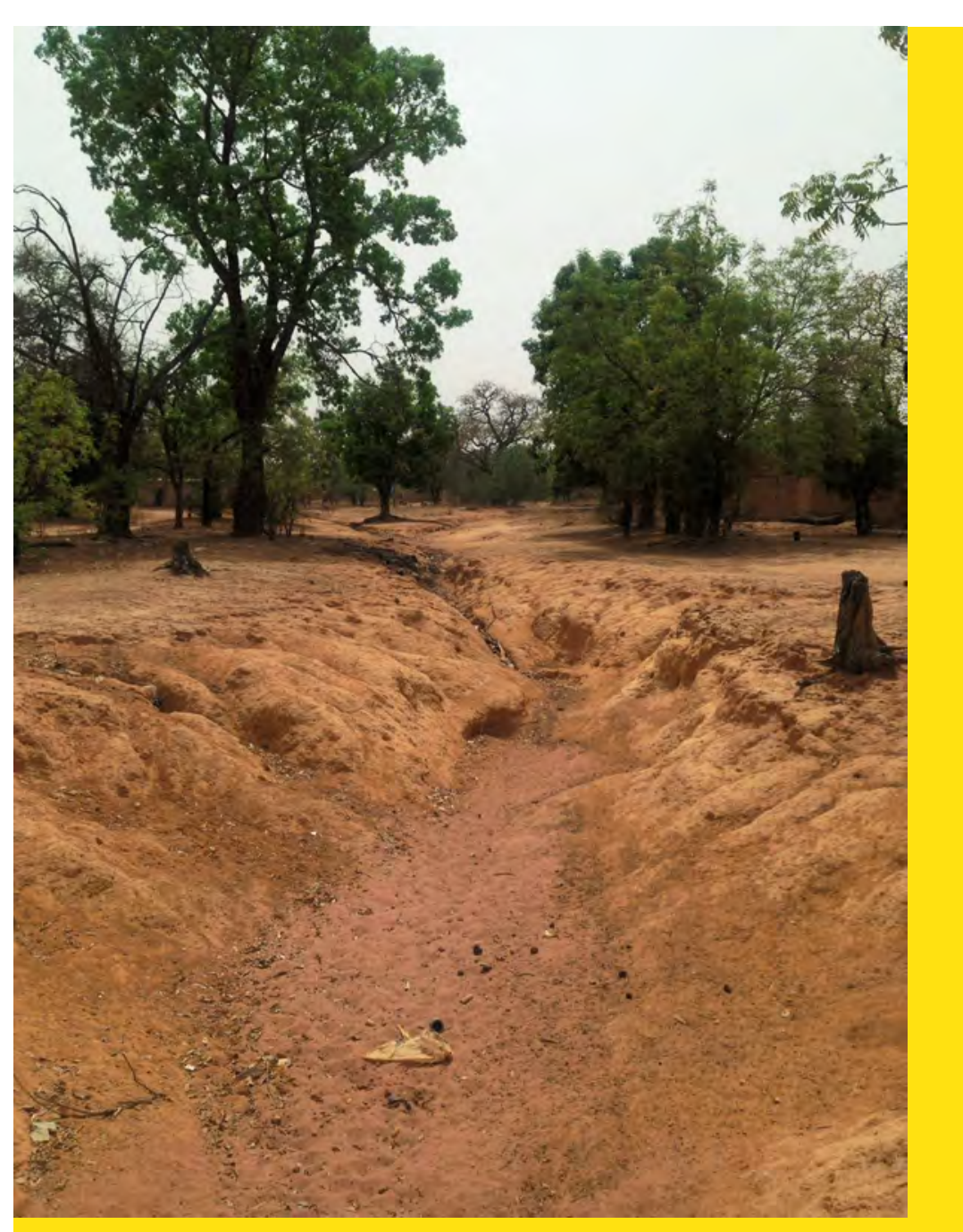

Soil erosion in Tiarako @ c L. Stiem-Bhatia/TMG Research

\section{Land tenure insecurity - a central challenge to agricultural productivity}

\author{
Agriculture and land degradation
}

In Burkina Faso, around $85 \%$ of the population depends on agriculture for their livelihoods. However, agricultural land is threatened by degradation. One third of the country's territory - 9,234,500 hectares - is already degraded, according to the Ministry of the Environment. Every year, a further 105,000 to 360,000 hectares are degraded.

Land degradation is the result of several factors, including demographic pressure, inadequate farming practices, poor land management, and climate change.

Hoping to slow the rate of land degradation and mitigate its impact on biodiversity and food security, the government of Burkina Faso has, since the 1960s, ratified numerous international conventions and adopted many policies in the area of sustainable land management (SLM).

Despite these considerable efforts, the adoption rate of land rehabilitation and protection practices remains low, and SLM initiatives are still very limited in terms of scope and impact over time. In the context of the accompanying research project, a study of SLM projects and programmes in the provinces of loba, Tuy and Houet showed that only three of the 10 projects analysed include a component on land tenure issues. This low level of attention given to land tenure issues could explain the limited accomplishments of these projects (Koudougou and Stiem, 2017). 


\section{Land tenure insecurity: an obstacle to the adoption of SLM techniques}

Studies carried out by the authors of this guide in the ProSol intervention area revealed that land tenure insecurity is a major obstacle to SLM, and that women, migrants, youth and agro-pastoralists are the primary groups affected by it (Koudougou et al., 2017; Koudougou and Stiem, 2017). Tenure insecurity hinders the application of SLM practices, particularly tree plantation, physical anti-erosive measures, and other measures that entail significant investment.

Commercialisation of cash crops, increasing mining operations, and the monetarisation of land transactions - within a context of a weak application of legal and regulatory provisions - aggravate land tenure insecurity for women and other vulnerable groups.

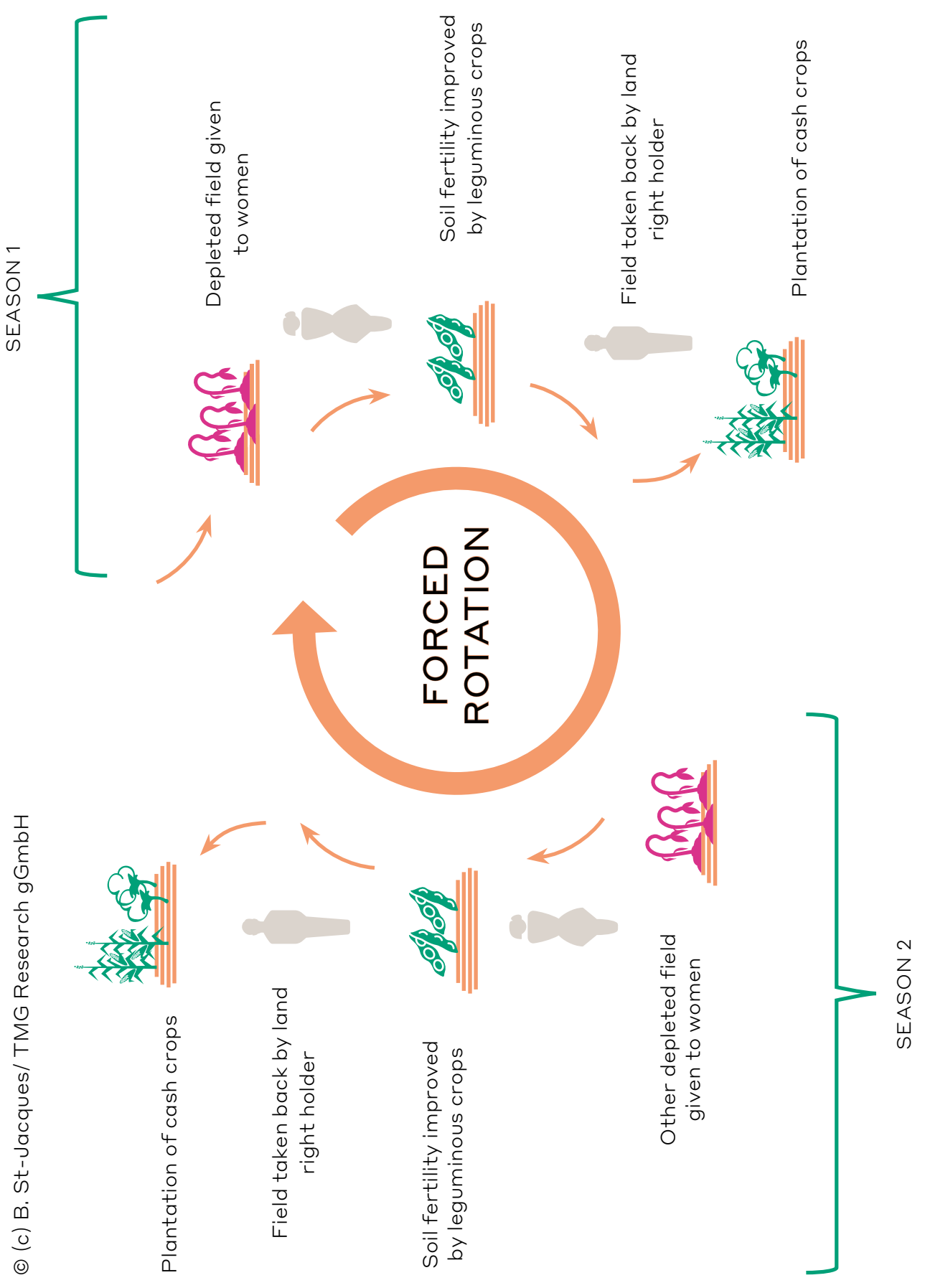




\section{Access to land for women in Burkina Faso}

In Burkina Faso, women play a major role in family farming; they are responsible for 52 per cent of agricultural production. But their access to land remains highly restricted. Under the traditional land tenure systems that still predominate in Burkina Faso, women enjoy only precarious (often annual) land use rights, and the land they are allowed to use is generally degraded.

Oftentimes, the land farmed by women is reclaimed by the (male) landowner, who then assigns the women another, less fertile plot of land for the next season. This forced rotation, and the impossibility of sustainably profiting from the efforts invested in improving soil fertility, undermines women's commitment to SLM.

In the study area, only women who are post-menopausal or who are farm heads (widows in most cases) can enjoy permanent land use rights. The situation varies greatly from one culture to another, depending on the status and rank of the women within the family.

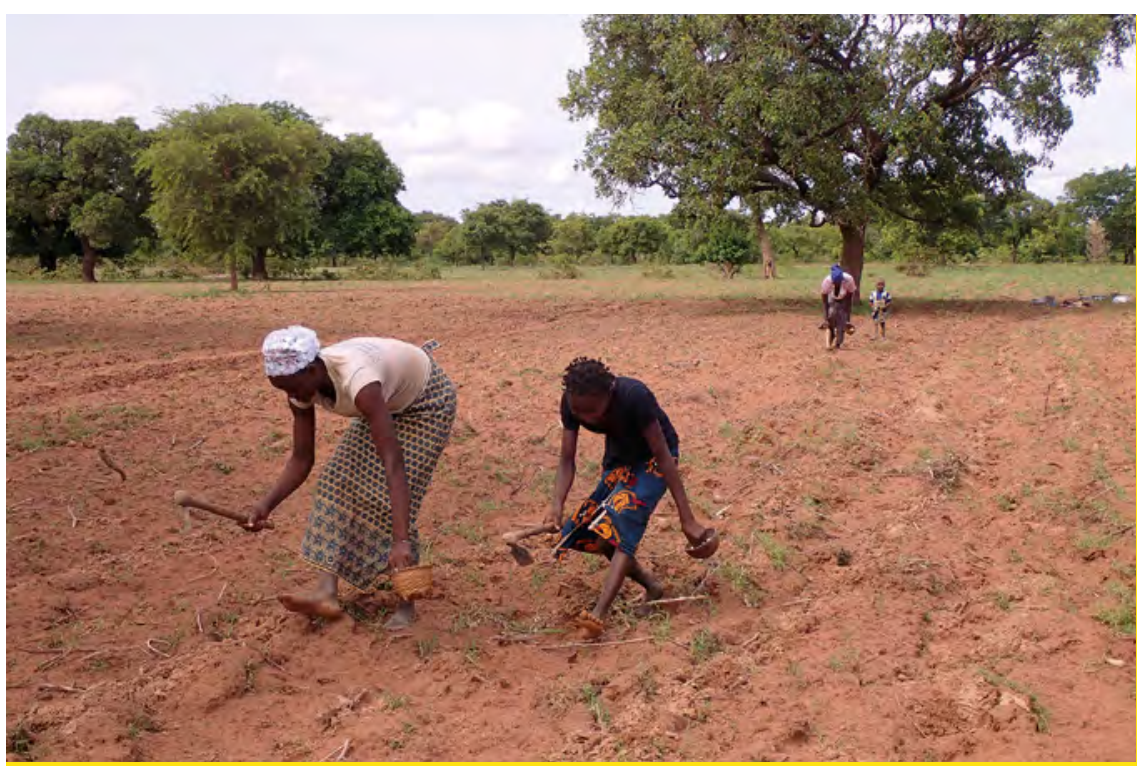

Women sowing maize in Tiarako (c) L. Stiem-Bhatia/TMG Research

\section{Limited implementation of land reforms}

Land rights in Burkina Faso are still largely based on customary and traditional land systems.

The land reforms initiated since 2007 and the rural land tenure law (034-2009), which was passed in 2009, attempted to formalise customary land rights. However, as of 2018 the land legislation has so far been implemented in just 112 of the country's 351 communes (municipalities). Moreover, even in those municipalities where the law has been implemented, its adoption by local actors is often limited. In the case of women, the situation is even more difficult because they are often neglected in law implementation and enforcement. 
Nevertheless, the 2009 rural land tenure law provides for the initiation of special programmes to secure land access for women based on quotas. However, their enforcement is limited because of a lack of financial and human resources.

\section{How to successfully} secure land access for women

\section{Securing land access in a context of a weak legal implementation}

In a context characterised by nascent statutory land governance and the absence of local land governance institutions such as the Rural Land Services, it is essential to select a path to securing land rights that is legitimate, accessible to the rural actors, and grounded in law.
By 'securing land rights' we mean "the set of processes, actions and measures of all kinds aimed at enabling the users of rural land to effectively deploy their productive activities, and protecting them from any dispute or disturbance in the exercise of their rights." (Bary, Ovédraogo, Sanou and Thiéba, 2005). Securing land rights therefore does not entail full ownership; that is, rights to transfer, sell or mortgage.

The issuance of land titles, such as the Rural Land Possession Certificate (APFR), to women has proven difficult in contexts where customary landowners do not hold any land title document. APFRs require the prior establishment of a Rural Land Services administration, but in many municipalities the resources needed to set up and ensure the proper functioning of such services are lacking. Moreover, the process of applying for APFRs entails costs that are beyond the means of many female farmers.

The process of securing access to land for women, piloted by the GRAF and TMG in the village of Tiarako, offers an alternative. The process is based on social legitimation: the land tenure agreements between women and heads of farming households are validated by all local actors. 


\section{Key steps in the process}

The objective of the process presented below is to facilitate dialogue on land tenure questions between the different stakeholders of the village community. Specifically, the purpose is to create the conditions for a broad consensus about land tenure agreements in accordance with the applicable land law and to focus on securing access to land for women.

The implementation of this process requires an inclusive approach involving frameworks for reflection, collaboration and expression on the question of securing land access for women. Based on the Tiarako experience, this process can span a period of four to six months.

The following principles should guide this approach as a whole:

The commitment and effective participation of all actors concerned.

The disregard of all pre-established solutions.

The negotiation of a consensus acceptable to all.

The process of securing land access for women involves several steps:

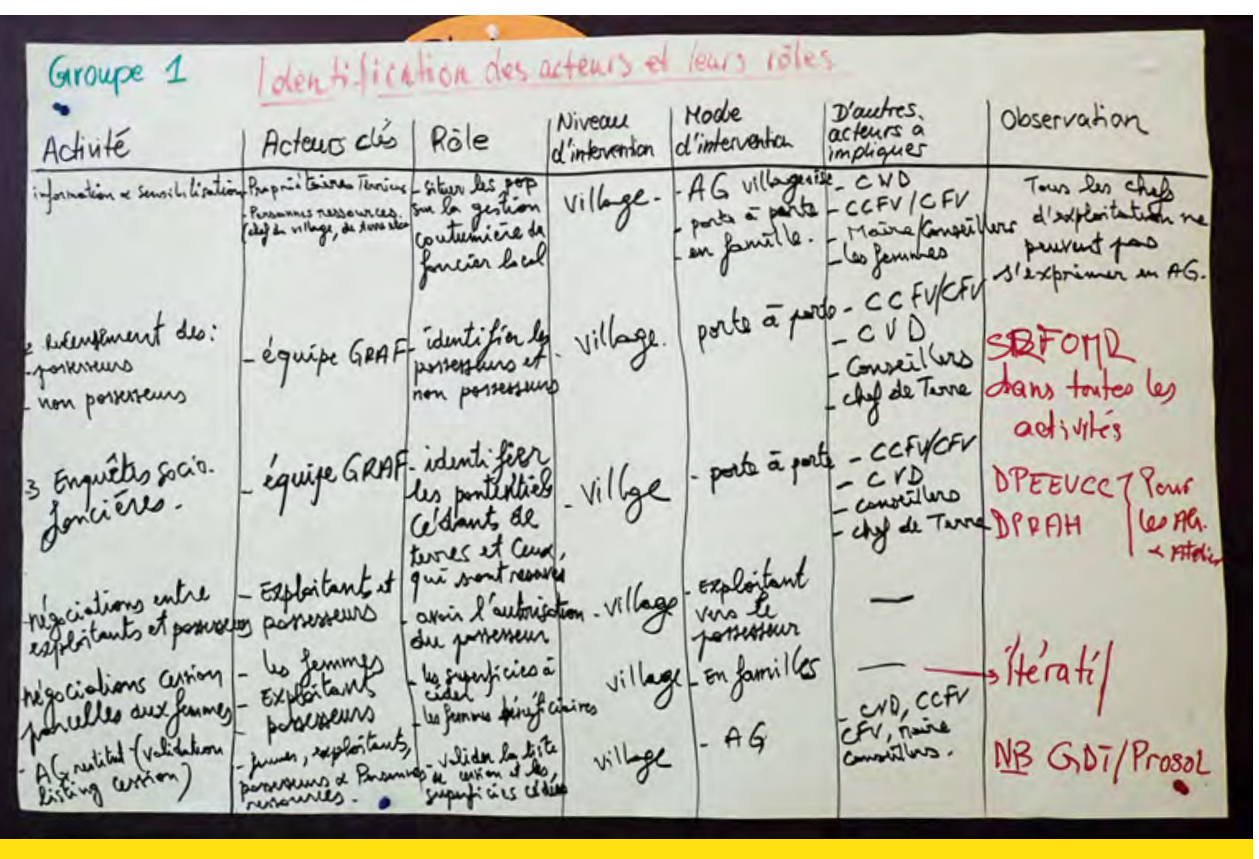

Identification of the actors and their roles during a launch workshop of the process in Tiarako @ L. Stiem-Bhatia/TMG Research

Co-conception and validation of the approach

The approach and all steps in the process should be designed and validated together with all of the actors concerned. A technical, multi-actor workshop provides the framework for the amendment and validation of the proposals. This workshop should also make it possible to establish and validate, together with the participants, a mapping of the actors involved. This mapping details the level of intervention, and role and responsibility of each actor. Each actor then commits to participating in the process and should know the role he or she will play. 
2 Launch at General Village Assembly

2 It is important that the outcomes of the technical, multi-actor workshop are shared with the entire village population so that the approach can be validated and legitimised. The discussions revolve around the legal framework supporting women's access to land. All concerns about the deeds to be formalised and the purpose of the process should be addressed. The assembly should build a general consensus in the village to commit to the process.

3 Awareness raising about securing land access for women

3 This step involves providing information about the legal provisions and policies to secure land access for women. Special emphasis should be placed on the benefits, both for the woman and her family. The main objective is to dispel all fears and worries connected to securing land access for women.

4 Social land tenure surveys

These surveys serve to collect information about the participating families by providing a list of the heads of farming households and of family members under their individual tutelage. The surveys also capture the intended type of agreement (grant or lease) and the size of plots to be transferred to women. To the extent possible, the village population should be involved in conducting these surveys - not only to reduce financial costs, but also to socially anchor the process.

The surveys should include other institutions, particularly technical public services, that provide reliable information about land rights, as well as resource persons who possess information about land in the area.
5 Census of participating heads of household

This step aims to distinguish between land owners and non-owners and identify farmers who agree to transfer a portion of their land to one or more women. In brief, this is a census of the heads of farming households who voluntarily engage in the process.

6 Negotiations between land owners and non-owners

In this step, the farmers who do not own land but would like to transfer land use rights to women negotiate with the landowners, seeking their agreement for the transfer of certain plots of their farms. This negotiation is bilateral and involves no third parties.

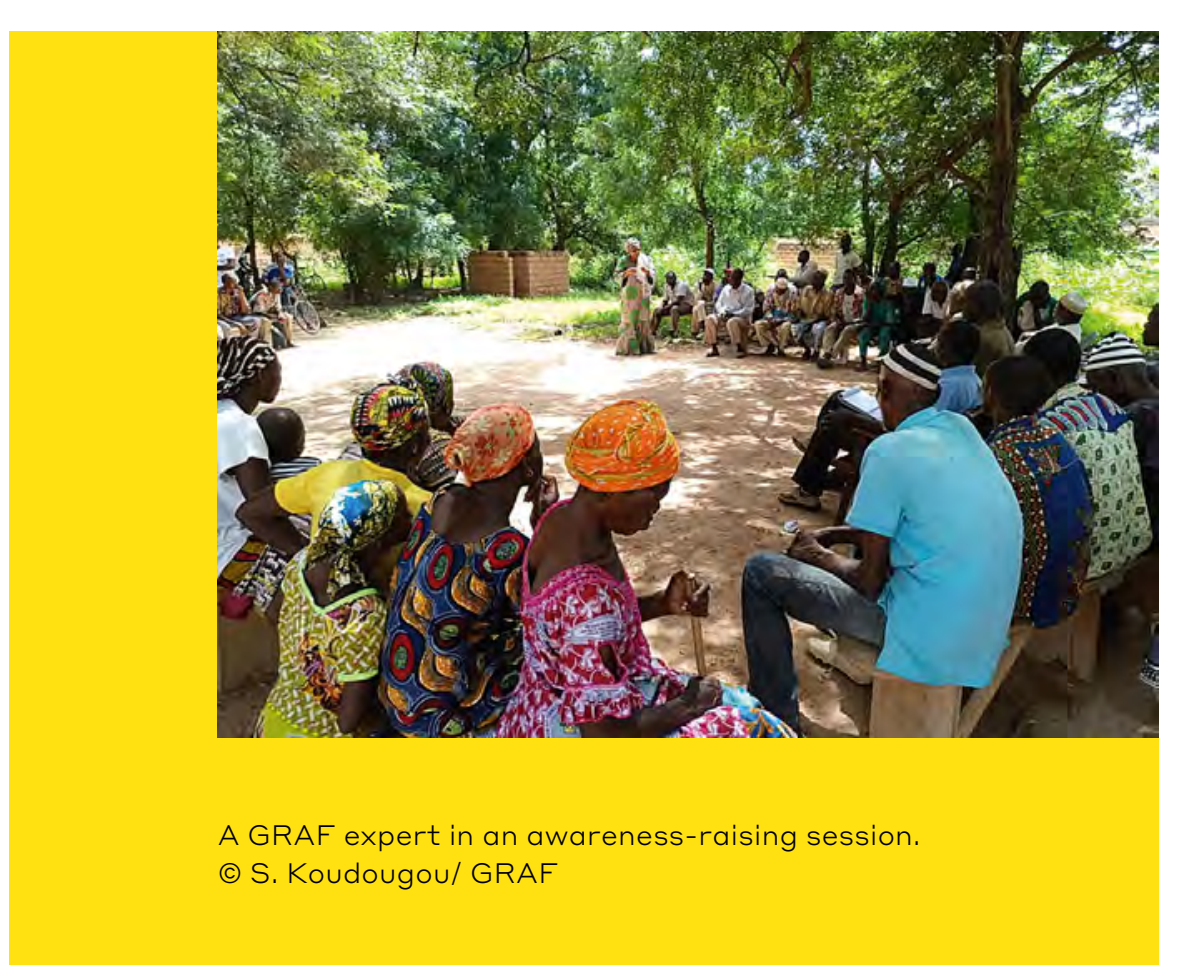




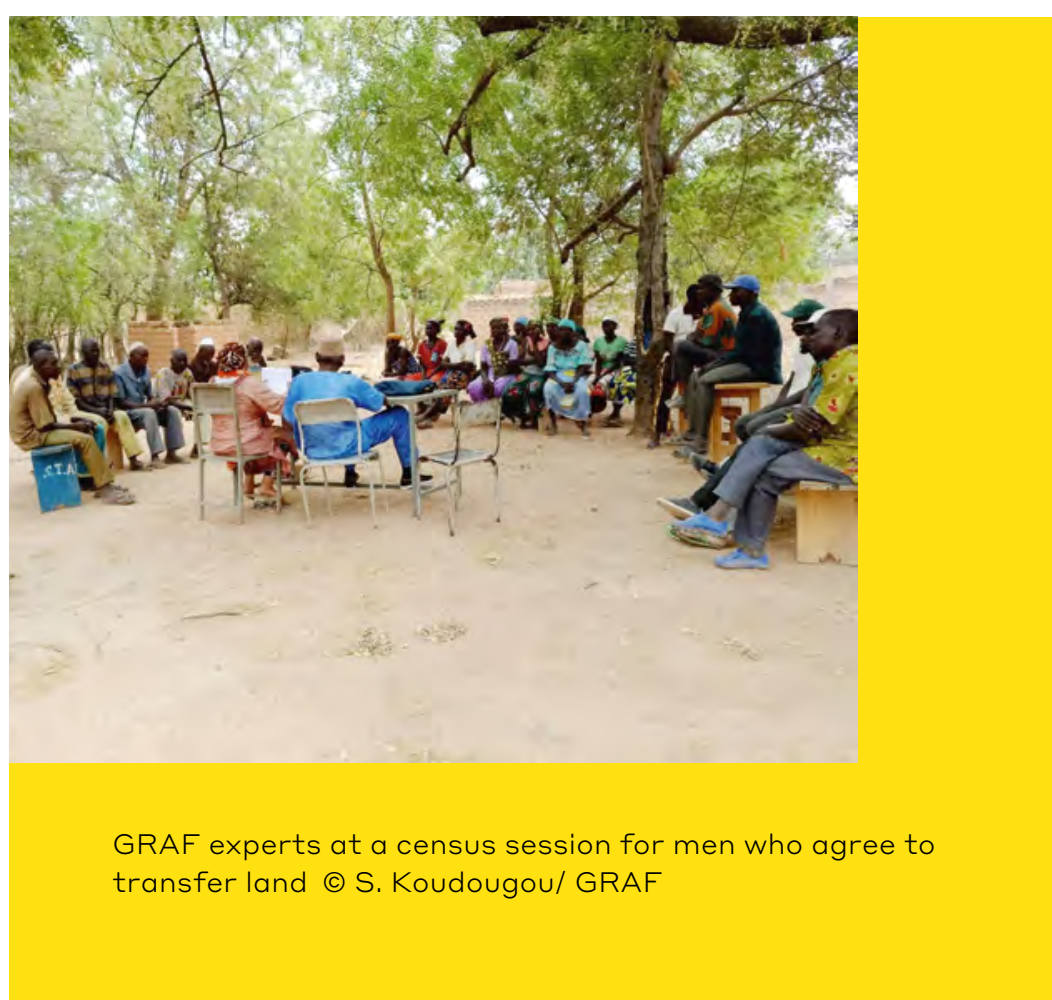

7 Negotiations between recipient women and heads of farming households

A focus group is organised to gather information on the main concerns of those men prepared to transfer land to women. The men should detail their concerns and the conditions under which they are prepared to transfer their land. At this point, it is useful to remind the parties of the advantages of securing women's access to land.

Another focus group is organised for the women. Here, the concerns of the men and their intentions of land transfers are discussed. Together, these focus groups generate consensus about the transfers and the associated conditions.
8 Assembly to validate the list of the head of farming households transferring land

A general assembly chaired by the president of the Village Development Council (CVD) validates the list of heads of farming households who have committed to transferring plots from their holdings to women. In the event of dispute, this list will be validated at a later stage.

9 Assembly to validate the list of land right transfers

A general assembly is organised to communicate the list of validated commitments and the accepted transfers, both with regard to the land surfaces and conditions. This information is incorporated into a single table, which is used subsequently in the process. The technical services and representatives of the municipality participate in this assembly.

10 Georeferencing the plots transferred to women

During this phase, the actual surface of the transferred plots is determined. Using GPS devices, the areas can be accurately recorded and included in the land agreement document. To minimise the operation's costs, it is useful to involve community members who know how to operate the GPS device.

11 Exchange session with the municipal administration

This phase is about informing the local authority about the land agreements; their type and conditions for implementation. During this meeting, the municipal council determines the key issues to be highlighted in the endorsement document, which will be communicated during the next village assembly.

12 Assembly to validate the local land agreements

This assembly offers the municipality an opportunity to verify the legitimacy of the land agreements.

Here, the conditions for the management of the agreements are discussed with the village elders and local committees (CVD, 


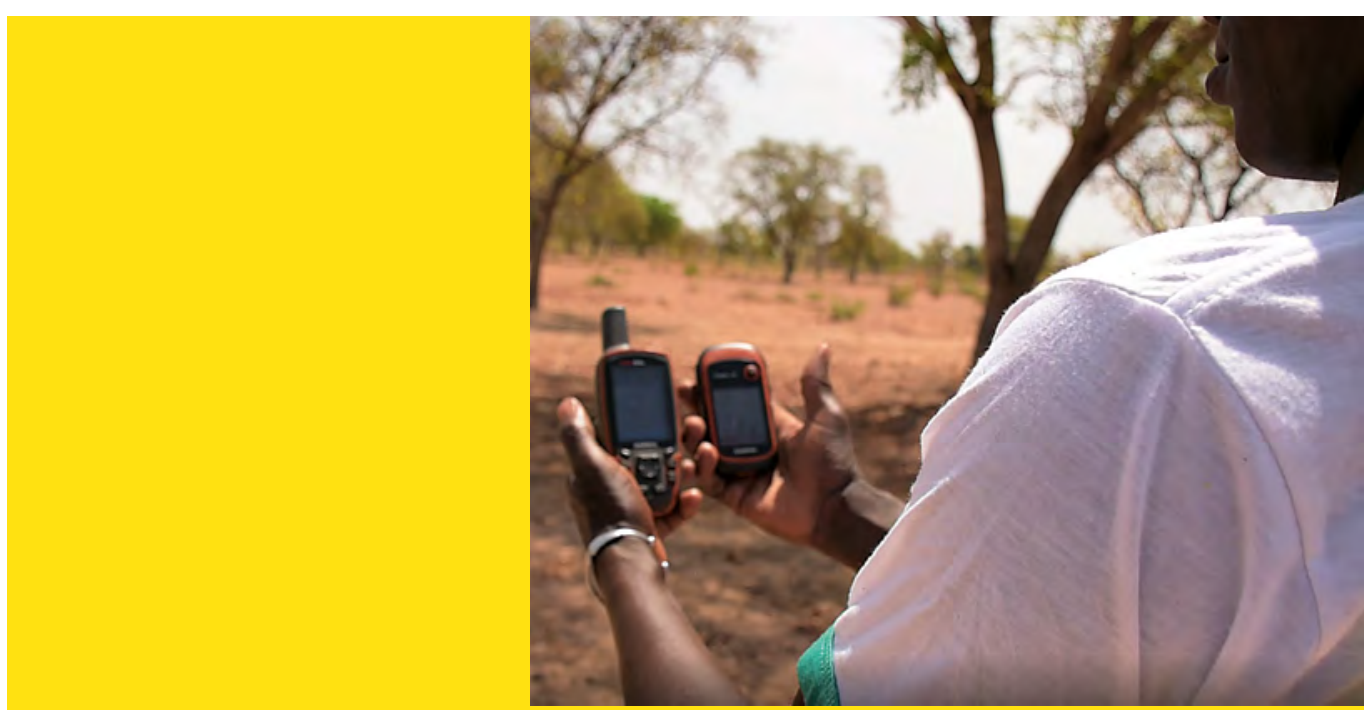

GPS recording of the secured parcels (C) Victor Emeghara

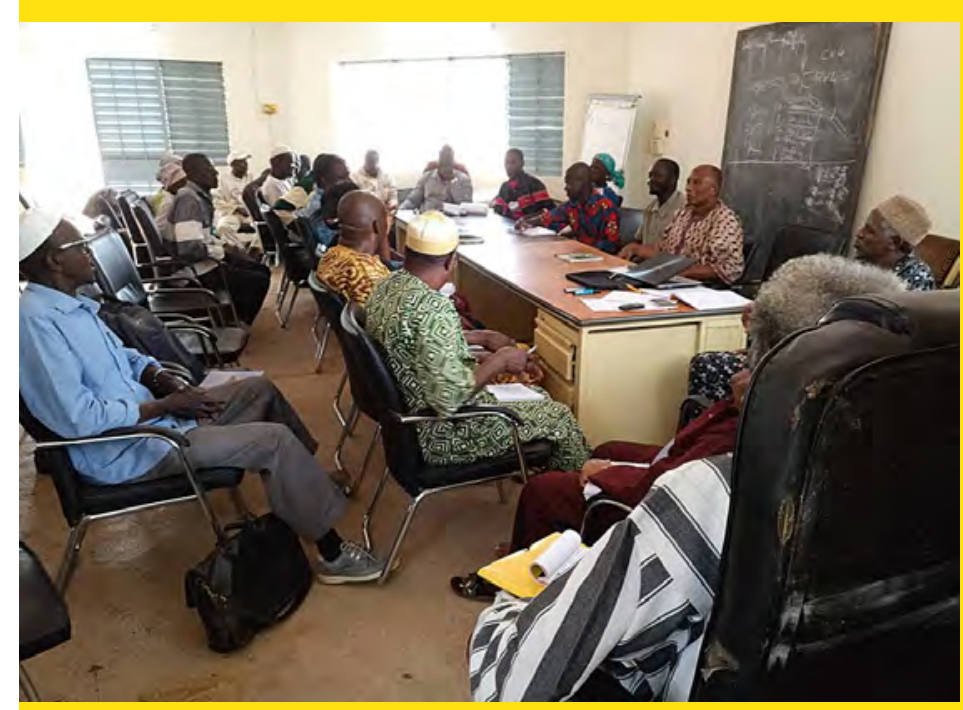

Technical meeting at the office of the municipal council, November 2017 @ S. Koudougou/ GRAF
CFV, CCFV), beneficiary women, and men. Various members of the village community act as witnesses.

Official minutes are taken of this general meeting. The municipality takes note of the negotiated land agreements. The mayor can take part in this village assembly.

13 Assembly to deliver the land agreements

This assembly, chaired by the president, validates the land agreements. Official minutes of the assembly should be taken and need to include a table of the land transfers. This table contains the names and signatures of the transferrers and of the recipient women, the areas transferred, the georeferenced coordinates of the transferred land, the neighbouring parcels, the type of the transfers, and their duration in the case of a lease.

14 Ongoing support for women beneficiaries

* Transferring land is not an end in itself. It is crucial to support the women beneficiaries in making use of the land they received. Specifically, it is recommended to:

provide training courses in sustainable land management;

offer follow-up technical services (e.g. agricultural extension and advisory services).

Some of these support activities, such as capacity building, may commence at the start of the land rights transfer process.

15 Continuous follow-up

The formation of a monitoring committee at village level is recommended. The mandate of this committee is to ensure the follow-up and surveillance of the land agreements. 
16 Multi-actor reflection workshop

A reflection workshop involving all of the actors is organised to discuss lessons learned and to facilitate the support process for the women who have secured access to land access.

17 Annual general assembly

An annual assembly is recommended to assess the enforcement of the land agreements. This allows clauses to be added, removed or adjusted in the existing agreements, and for new agreements to be considered. Any new land agreement must be documented, endorsed by village authorities and recognised by the municipal administration.

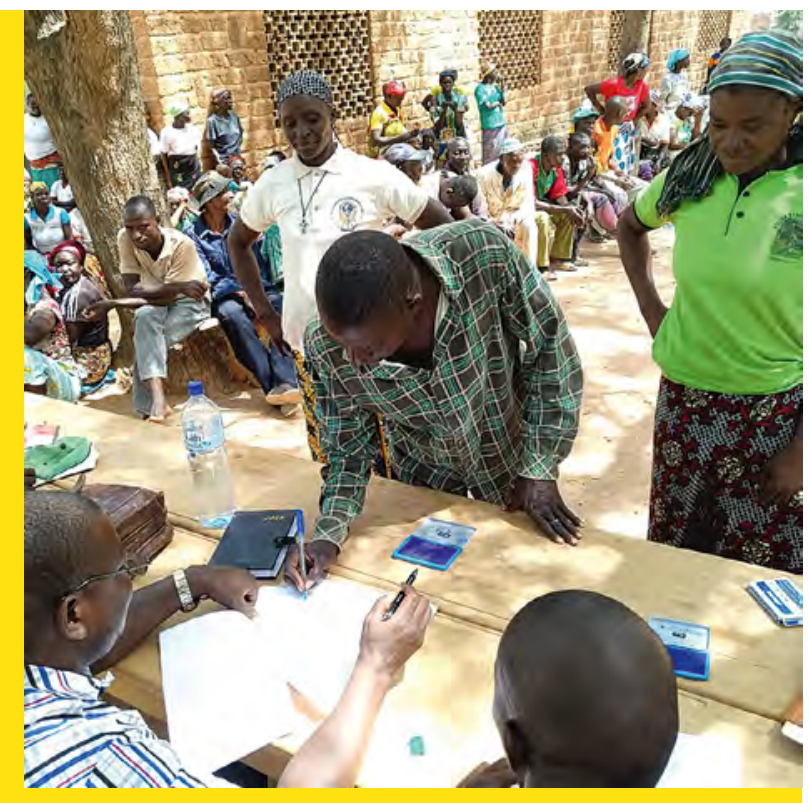

A man transferring land rights to his wives by signing his name on the Official Minutes (CS. Koudougou/ GRAF

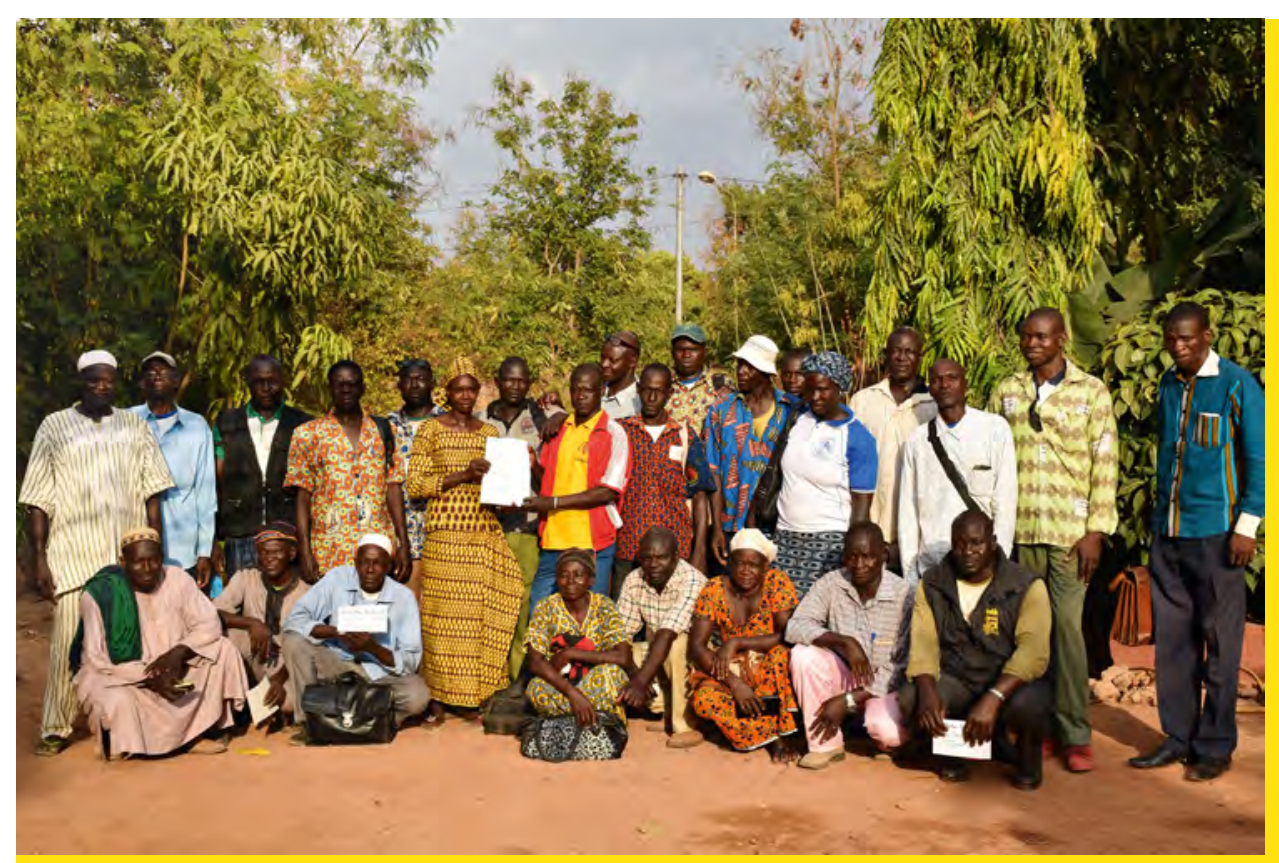

Representatives of Tiarako holding the Official Minutes document at the debriefing workshop. (c) A. Bague 


\section{Process of securing land access for women}

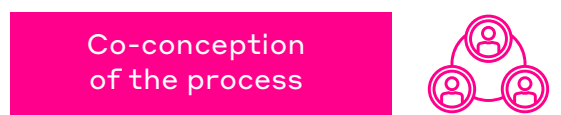

Multi-actor consultation to reach consensus about the process

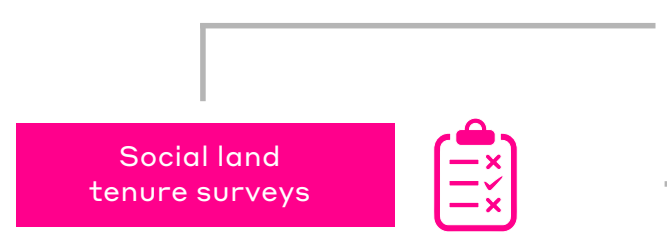

Understanding of current local tenure systems

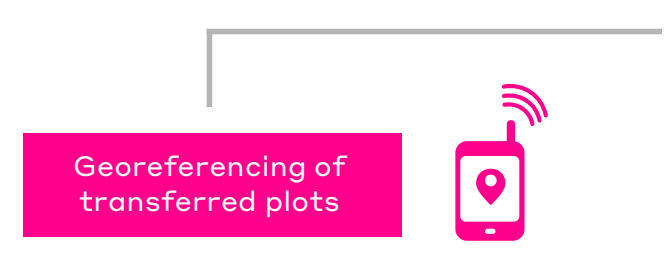

Georeferencing and

documentation of the transferred plots

Valorisation of

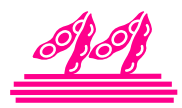

Support of women beneficiaries in farming their plots, provided by their families and technical services transferred plots

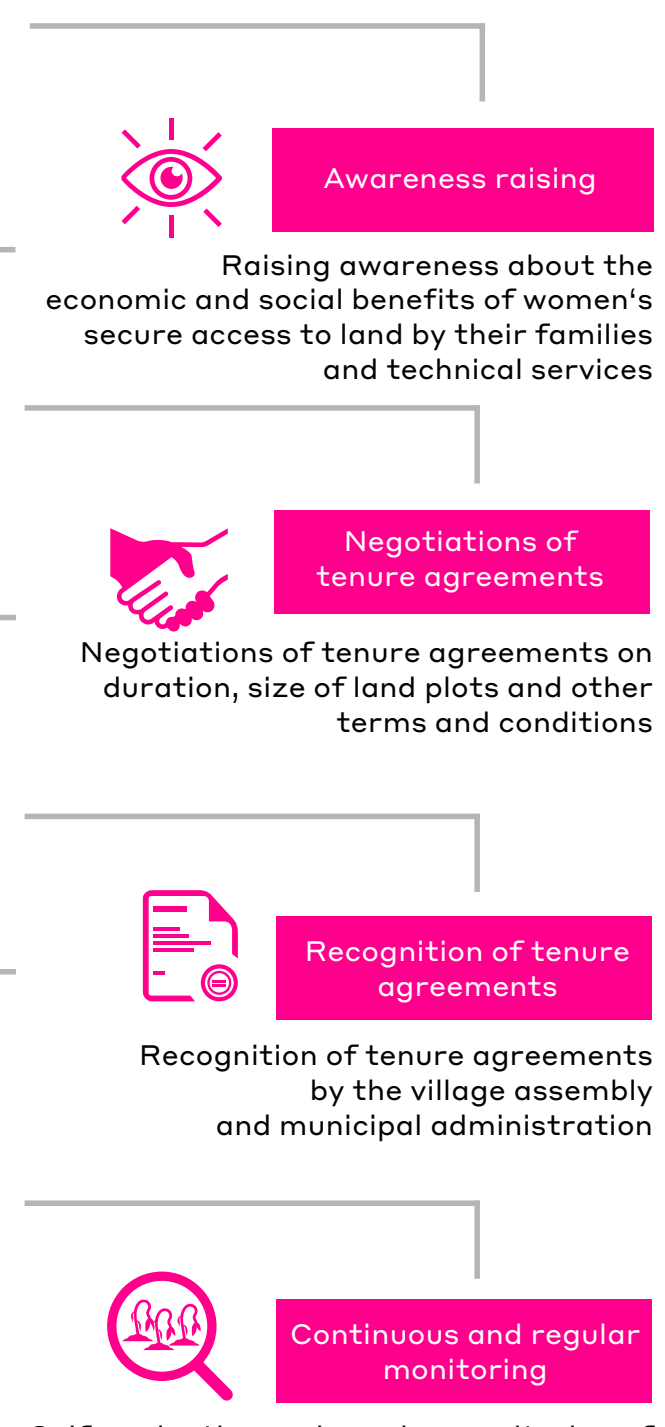

Self-evaluation and regular monitoring of tenure agreements

\section{Guiding principles for a successful process}

The conduct and success of the process of securing land access for women, as tested by GRAF and TMG, is founded on the following guiding principles:

Preliminary in-depth diagnosis

The process should begin with analysis and documentation of the modes of land tenure (including those of disadvantaged groups), any land conflicts, the average size of the farms, etc. This diagnosis makes it possible to reduce conflicts and other risks once the process is underway.

2 Inclusive and effective participation of the local actors

From the outset, the process requires strong commitment from the relevant stakeholders. The participating landholders and farming households, village authorities and the municipal administration are in charge of the process. To this end, make sure that the process of securing land is not a matter for experts or consultants but for local actors: customary and traditional chiefs, religious figures, opinion leaders, resource persons, civil society organisations, etc.

3 Transparency and anchoring in social legitimacy

For the local community to take full ownership of the process, ensure that it is transparent. Each stage of the process must be validated in a village assembly to build and strengthen consensus and social legitimacy. The concerns of local actors about the process and its purpose need to be taken into account.

4 Legality anchored in legitimacy

The process of securing land for women should not only be anchored in legitimacy but also comply with the legal and regulatory texts pertaining to rural land. The municipal administration and its technical services must recognise the negotiated land agreements. Concomitantly, the deeds securing land 
rights should be accessible (content controlled by the local actors, affordable cost, etc.).

5 Creation of an amicable environment

Identify the points of disagreement and reservations to gain the confidence of the parties involved, so that they can negotiate in a non-confrontational climate and arrive at consensual solutions.

\section{Conclusion}

The alternative process for securing women's access to land demonstrates that legitimacy and legality can be achieved by strong and effective collaboration with local actors. In effect, this process was carried out in a rural municipality that did not yet have a Rural Land Service. The village land governance bodies (CFV and CCFV) were set up only recently, and are not yet adequately equipped to fully fulfil their roles.

The process for securing women's access to land piloted by GRAF and TMG involves relatively low costs, when compared to the issuance of land deeds provided for in law 034-2009 (obtaining APFRs and land deeds). Moreover, the process was carried out without incurring exorbitantly high costs when the formal land institutions were still in their infancy.

It is up to the relevant actors to make use of this guide, which offers them a means of efficiently accompanying the stabilisation of the rights of women to rural lands. 


\section{References}

Bary, H., Ouédraogo, H.M.G., Sanou, S. and Thiéba, D. (2005). Di agnostic de la situation de sécuri- sation foncière en milieu rural. Rapport final. Ministère de l'agriculture, de

l'hydraulique et des ressources halieutiques, Burkina Faso.

Koudougou, S., Stiem-Bhatia, L., Bary, H. and Tall, F. (2017). Genre, foncier et gestion durable des terres au Burkina Faso. Potsdam, Germany.

Koudougou, S. and Stiem, L. (ed.) (2017). La Gestion Durable des Terres au Burkina Faso: une analyse d'expériences de projets dans le Hovet, le Tuy et le loba. Potsdam, Germany. https://doi.org/10.2312/iass.2017.006

Saito, K., Mekonnen, H., and Spurling, D. (1994). Raising the productivity of women farmers in sub-Saharan Africa. World Bank Discussion Papers, Africa Technical

Department Series No. 230. Washington, DC, World Bank.

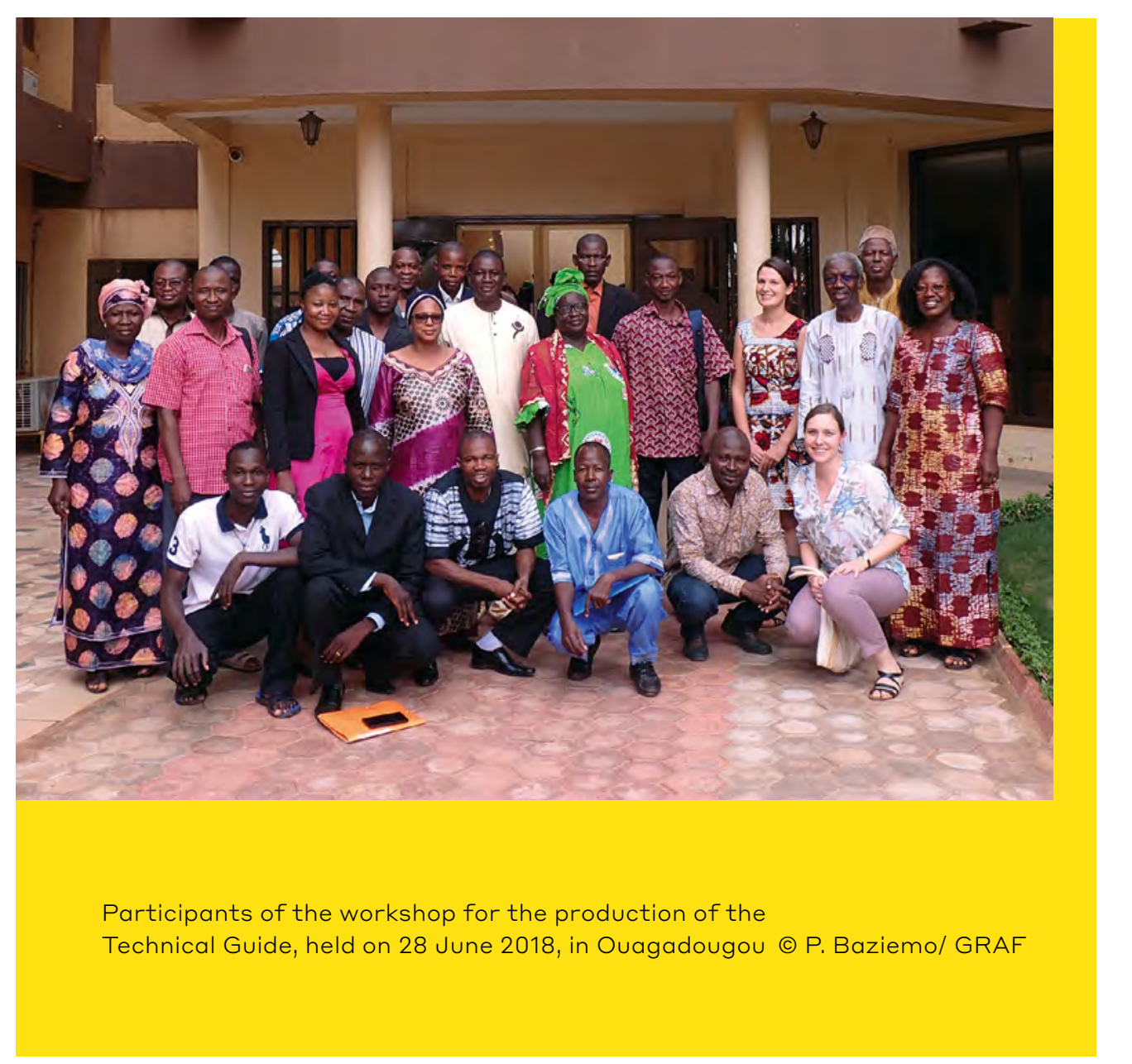




\section{TMG Research and GRAF Technical Guide July 2020}

TMG - Think Tank for Sustainability

TMG Research gGmbH

EUREF-Campus 6-9

10829 Berlin, GERMANY

Telephone: (+49) 3092107407 00

Email: info@tmg-thinktank.com

Website: www.tmg-thinktank.com

Groupe de Recherche et d'Action sur le Foncier (GRAF)

11 BP 146 Ouagadougou 11, BURKINA FASO

Telephone: (+226) 25341457

Email:graf@fasonet.bf

Website: www.graf-bf.org

This publication was made possible with financial support by the German Federal Ministry for

Economic Cooperation and Development (BMZ). 